\title{
FORMATION OF SER-WHORLS IN RAT-LIVER CELLS INDUCED BY THE ACARICIDE, TETRASUL
}

Sir,- The acaricide, tetrasul (4'-chlorophenyl-2,4,5-trichlorophenyl sulphide), is undergoing short- and long-term toxicity studies with different species of animals in our laboratory. In the course of this work, a common finding has been the appearance of cytoplasmic inclusion bodies in the liver parenchymal cells of rats given diets containing tetrasul.

Further experiments were conducted to study the nature and formation of these inclusion bodies. For this purpose, Wistar rats (body weight $40-60 \mathrm{~g}$ ) received $3000 \mathrm{ppm}$ tetrasul in the diet for 6 months. After 2, 4 and $26 \mathrm{wk}$, two male and two female animals were sacrificed and the livers examined under the light and electron microscope. In the ultrastructural study, tissue fixation was carried out in a $1 \%$ solution of osmium tetroxide in veronal acetate buffer (pH 7.3-7.5) for $2 \mathrm{hr}$ at $4^{\circ} \mathrm{C}$ (Palade, J. exp. Med. 1962, 95, 285; Daems, 5th int. Congr. Electron microscopy, Philadelphia, Edited by S. S. Breese, 1962, Academic Press, New York) and impregnated with equal parts of methyl methacrylate and styrene. The 500$700 \AA$ sections were stained with a 5\% aqueous uranyl acetate solution and thereafter with the lead stain A of Karnovsky (J. biophys. biochem. Cytol. 1961, 11, 729).

In the centrilobular area, and to a lesser extent in the periportal area, swelling of the parenchymal cells with enlargement of the nuclei was observed histologically at $2 \mathrm{wk}$, these changes becoming more marked as time progressed. At $2 \mathrm{wk}$, smooth endoplasmic reticulum (SER) was swollen and fragmented but the mitochondria remained unaffected. Cytoplasmic inclusions were occasionally present in liver cells. At $4 \mathrm{wk}$, the number of cells with cytoplasmic inclusions increased and after $26 \mathrm{wk}$ one or more of these inclusions were seen in nearly all liver parenchymal cells. The inclusion bodies, usually laminated or round and sometimes triangular or lobulated, frequently contained one or more central vacuoles which gave an oil red O positive stain. They consisted of SER in a tortuous form. Sometimes a transition from rough endoplasmic reticulum (RER) to SER and then to a tortuous figure was seen (Fig. 1). An increase in the size and incidence of these figures was associated with a loss of the free SER. Sometımes the inclusion bodies were three tımes as large as the nucleus.

Similar figures have been reported by other workers under different titles. Ashworth et al. (Am. J. Path. 1965, 47, 6) reported "myelin like figures" in hepatocytes of rats given thioacetamide. Timme \& Fowle (Nature, Lond. 1963, 200, 694) reported "whorls" in liver cells of rats given p-dimethylaminoazobenzene. In a review article, Haguenau (Int. Rev. Cytol. $1957,7,425)$ referred to the presence of "Nebenkernen", "onion bulb pictures" and "fingerprint figures" in the pituitary gland of oestrogen-treated rats. Palay \& Palade ( $J$. biophys. biochem. Cytol. 1955, 1, 69) described "whorls of shallow cisternae" in sympathetic ganglion cells of untreated rats.

The various forms in which the inclusion bodies appear make it difficult to find a name applicable to all its shapes. In our work, osmiophilic inclusion bodies also occurred without whorls. These gave a positive stain with oll red $\mathrm{O}$ and were probably condensed liposomes. They were also observed in hepatocytes of untreated animals but to a lesser degree. Fragmented SER was often enclosed in a whorl. The outer layers of one whorl sometimes surrounded SER, condensed liposomes or mitochondria thus resulting in bizarre forms. Undoubtedly, the whorls consist of SER which can either originate from newly-formed fragmented SER or can be produced by the loss of ribosomes from RER. 
The whorls reported in the scientific literature occur normally (Palay \& Palade, loc. cit.) or are formed in response to chemical agents. Tetrasul appears to be the first chlorinated acaricide that causes whorls in liver parenchymal cells. Recently Ortega (Fedn Proc. Fedn Am. Socs exp. Biol. 1962, 21, 306; Lab. Invest. 1966, 15, 657) has shown that DDT given in large doses to rats for a long time also induced "myelin figures".

Work is in progress to follow the primary stages of whorl development induced by acute doses of tetrasul.

\author{
H. G. VERSCHUUREN, \\ Laboratory of Toxicology, \\ National Institute of Public Health, \\ Utrecht, \\ The Netherlands
}

Acknowledgements-The author would lıke to thank N.V. Phılıps Duphar for supplyıng tetrasul, Mr. J. D. van Wijngaarden of N.V Philips Duphar for his valuable technical assistance and Dr. J. S. Teppema of our Institute for his help.

Fd Cosmet. Toxicol. Vol. 5, p. 451. Pergamon Press 1967. Prınted in Great Britain

\title{
SAFETY EVALUATION OF AN EPOXY-RESIN LACQUER USED IN FOOD CONTAINERS
}

Sir,--Epoxy resins are being used on an increasing scale by the food industry for the surface protection of cans, tubes and large containers. A toxicity test was conducted on a lacquer which was based on an epoxy resin but was produced without the use of solvents. The test substance was a liquid unmodified epoxy resin of the diphenylolpropane (bisphenol-A) type (Araldit GY 250) with two polyamine hardeners (HY 830 and HY 850). In this study, normally hardened and washed free lacquered foils were used.

Rats were fed for 90 days on diets containing $1 \%$ powdered lacquer, $1 \%$ powdered lacquer heated with human foodstuffs commonly stored in lacquered cans or combined extracts of lacquer foils, using distilled water, $3 \%$ acetic acid, $10 \%$ ethanol and peroxide-free ether as the extractants. The test materials were incorporated in the diet at a level about 150 times that expected to migrate into the food during storage. A control group received similar amounts of quartz powder of comparable particle size. Compared with controls, no effect was seen on growth, haemoglobin concentration, survival, organ weights and pathology.

Although this particular formulation exhibited a low order of short-term toxicity, the conclusion cannot be drawn that all epoxy resins are harmless. In fact, earlier work suggests that products of this type can be hazardous (Bär, Bundesgesundheitsblatt 1962, 5, 74; Uhde \& Woggon, Die Nahrung 1966, 10,601). Toxicity depends particularly on the content of free epoxy groups in the resin and also on the nature of the hardeners, stabilizers and any possible contaminants that may be present.

A detailed account of this work is to be published in the Deutsche Lebensmittel-Rundschau.

H. D. Cremer and G. Wilmes, Institut für Ernährungswissenschaft I, Universität Giessen, Germany 


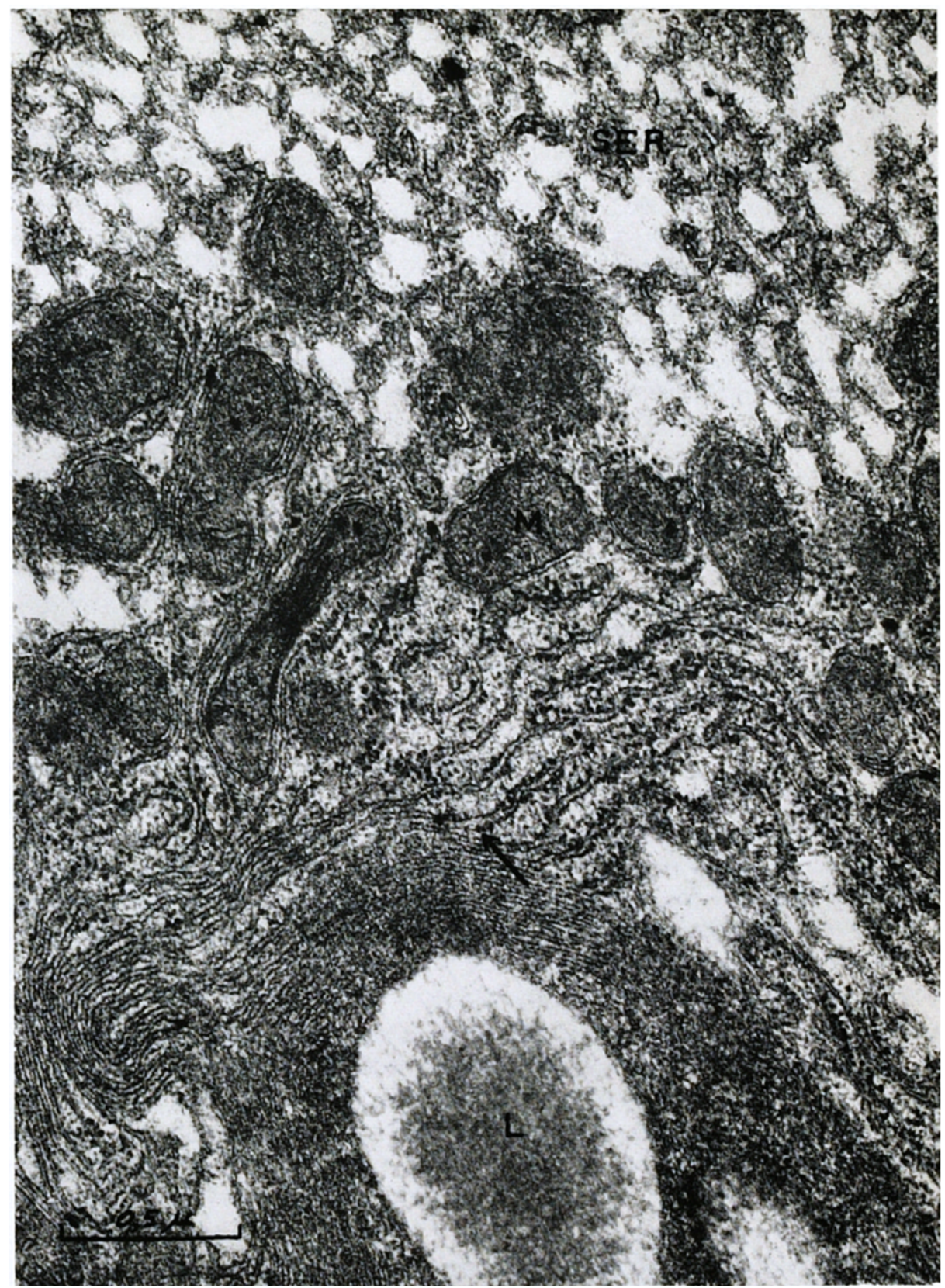

FIG. 1. Electronmicrograph showing a part of a whorl consisting of parallel arrangements of SER enclosing a liposome (L). At the upper part of the whorl a direct transition can be seen from RER to smooth membranes (arrow). In the upper part of the figure fragmented SER can be observed. $M$ represents a mitochondrion. 